\title{
Genetic markers for glutamic acid decarboxylase do not predict insulin-dependent diabetes mellitus in pairs of affected siblings
}

Tina Rambrand • Flemming Pociot •

Kjersti S. Rønningen • Jørn Nerup • B. K. Michelsen •

The Danish Study Group of Diabetes in Childhood

Published online: 7 February 2007

(C) Springer-Verlag 2007

Erratum to: Hum Genet 99:177-185

DOI 10.1007/s004390050334

The original version of this article unfortunately contained a mistake. The second initial of K. S. Rønningen was missing.

The online version of the original article can be found at http://dx.doi.org/10.1007/s004390050334.

The Danish Study Group of Diabetes in Childhood is an association of pediatricians with a special interest in diabetes research. For participating hospitals see (Pociot, 1993)

T. Rambrand · B. K. Michelsen ( $\square)$

Hagedorn Research Institute, Niels Steensens Vej 6,

DK-2820 Gentofte, Denmark

F. Pociot $\cdot$ J. Nerup

Steno Diabetes Center, DK-2820 Copenhagen, Denmark

K. S. Rønningen

Institute of Transplantation Immunology,

The National Hospital, N-0027 Oslo, Norway 